\title{
Application of SCS-Curve Number Method to estimate Runoff using GIS
} for Gali-Bandawa Watershed

\author{
Zahraa Mahmood Klari¹, Sayran Ahmed Ibrahim² \\ 1,2Water Resources Department, College of Engineering, University of Duhok, Kurdistan Region - IRAQ
}

\begin{abstract}
In any hydrologic study, the most important parameter is the runoff which is necessary for designing any hydraulic structure, and for determining the risk of flood. As there is a scare in the availability of runoff data in many sites, hydrologists have developed indirect methods to determine the runoff to accelerate the program of watershed management for conserving and developing water resources management. Many methods are used to estimate the runoff; Soil conservation curve number (SCS-CN) method is widely used and gives a reliable result compared with other methods. The present study aims to calculate the surface runoff depth depending on the SCS-CN method using a Geographic information system (GIS). For this Gali-Bandawa watershed in Duhok, north of Iraq has been selected, the geographical area of this watershed is about $92 \mathrm{Km} 2$ and the average annual rainfall is around $620 \mathrm{~mm}$, the weighted $\mathrm{CN}$ is 76 . The results show that the depth of annual average runoff for the Gali-Bandawa watershed is $70 \mathrm{~mm}$, and the average volume of runoff from the same watershed is $6470360 \mathrm{~m} 3$. The amount of runoff represents $11.4 \%$ of the total annual rainfall. This approach could be applied in other Iraqi's watersheds for the planning of various conservation measures.
\end{abstract}

Keywords: GIS, SCS-CN method, rainfall-runoff, FORTRAN programming, Gali-Bandawa watershed.

\section{Introduction}

Estimation of runoff is an important part of this study because Iraq is within the semi-arid region. The climate of the region is characterized by its fluctuation in rainfall and periods of droughts (Al-Ansari, 1998). Recently, the water scarcity issue is becoming more serious due to several factors. Among them is the increasing water demand, high population rate, effect of global warming and poor management and planning of the water resources during the last four decades. In addition, water policies of the neighboring countries enforced another burden where huge dams were built on the upper parts of the Tigris and Euphrates Rivers in Syria and Turkey. And this led to the reduction of the flow rate of both rivers inside of Iraq. So it is important to build dams in suitable areas to guarantee water reserving for drought seasons (Al-Ansari, 2011).To meet the scarcity of water shortage, building many dams that depend on rain water as a major source is a vital serious matter that must be studied by hydrologists and administrators, especially in areas where there is no measurement of the runoff. Only rainfall measurements exist, so several methods are used to estimate runoff). Most hydrological studies faced a problem with determining the amount of runoff, especially when there are records of precipitation and no records for runoff. Runoff is happening when the precipitation speed exceeds the speed of infiltrated water into the soil. All area that covers all lands contributing runoff to a common point called a watershed (Al-Jabari, AbuShark, and Al-Mimi, 2009). In Iraq, the accurate information of runoff is not available in most areas and is limited. The Soil Conservation Services Hydrologists constantly face the problem of estimating direct runoff in which no available records for a specific watershed. Soil Conservation Service (USDA, 1985) SCS curve number method is an acceptable tool in hydrology, which uses a factor for land conditions called "the curve number" and its responsiveness to four important catchment properties, i.e. land use, soil type, antecedent moisture condition, and surface condition. In a recent study of runoff (Lange, Ghanem, Hussary, Leibundgu, and Greenbaum, 2000) have studied the runoff on a 
steep $180 \mathrm{~m}^{2}$ Mediterranean Karts environment. The results showed that on a dry plot about $16 \mathrm{~mm}$ of rainfall was needed before terrain other bar rock generated runoff. Overall $16 \%$ of rainfall turns into runoff, while in the following day $73 \%$ of the applied rainfall arrived at the outlet of the wet plot. Shadeed and Almasri (2010), have assessed the flow modeling in West Bank watersheds using GIS and SCS - CN method. They demonstrated that by integrating of GIS with SCS - CN method, a powerful tool will be provided to estimate the runoff. Another study has been studied in the Kurdistan Region of Iraq drought period during the seasons 20072008 and 2008-2009 that affected the human and economic activities of the region. Macro rain-water harvesting (Macro RWH). This technique is based on the Soil SCS-CN method and WMS to estimate the runoff. The results of the application of the WMS model showed that about 10.76 million cubic meters could be harvested. The results also showed that the quantity of the harvested runoff was highly affected by rainfall depth, curve number values, antecedent moisture conditions (AMC), and the area of the basins (Zakaria, Mustafa, Mohammed, Ali, Al-Ansari, and Knutsson, 2013). Shah, Motiani, Prakash, and Mehmood (2017) have determined the runoff depth using the Soil conservation Service (SCS-CN) method using a Geographical Information System (GIS) environment. For this, Meshwo River Watershed located in Dhansura - Aravalli district of Gujarat was selected and the Natural Conservation Service- CN method was adopted for estimating the runoff. Average rainfall data was used to calculate the average runoff. The runoff amount represented about $26 \%$ of the average rainfall for the year 2015. Khidir and AL-Sha'ar (2017) applied Watershed Modeling System (WMS) to estimate the runoff using three different synthetic unit hydrograph methods, were NRCS, Snyder, and Clark, and to choose the best one according to some statistical test result, he found that the Snyder method results is are closer to the recorded data. Eshanthini Vijayalakshmi, and Raji
(2018) used GIS and remote sensing as a tool to calculate the volume of runoff applying SCS-CN mode, they estimate $\mathrm{CN}$ values depending on the natural resources conservation standard table. They concluded that the model SCS along with GIS would give a more reliable runoff for ungagged watersheds

In this paper, Gali-Bandawa was selected as a study area because it has been suggested by directorate of Duhok dam for constructing a dam at its outlet. To estimate runoff, GIS tool was used to prepare, classify and identify both soil type and land use maps for the selected area, and by develop the runoff curve number map, Finally, SCS curve number method used to estimate runoff with help of a FORTRAN program to facilitate the solution to obtain the runoff from daily rainfall data.

\section{Study Area}

The study area, named Gali Bandawa or Bandawa, is located in Duhok city (North of Iraq). The watershed outlet coordinate has a Latitude $(\mathrm{N})$ is $36^{\circ} 46^{\prime} 28^{\prime \prime}$ and a Longitude (E) is $43^{\circ} 04^{\prime} 30^{\prime \prime}$ Figure (1). The watershed has a geographical area around $92 \mathrm{Km} 2$; the Basin slope is $18.2 \%$ and the maximum slope length is $16.1 \mathrm{~km}$. The area, in general, has a moderate slope around the dam and a steep slope in some higher parts of the basin, especially in the mountains. The maximum, mean, and minimum elevations are correspondingly 1330m, 502m found by GIS tool. The area occupies a valley of seasonal streamflow, and the source of runoff is the rainfall.

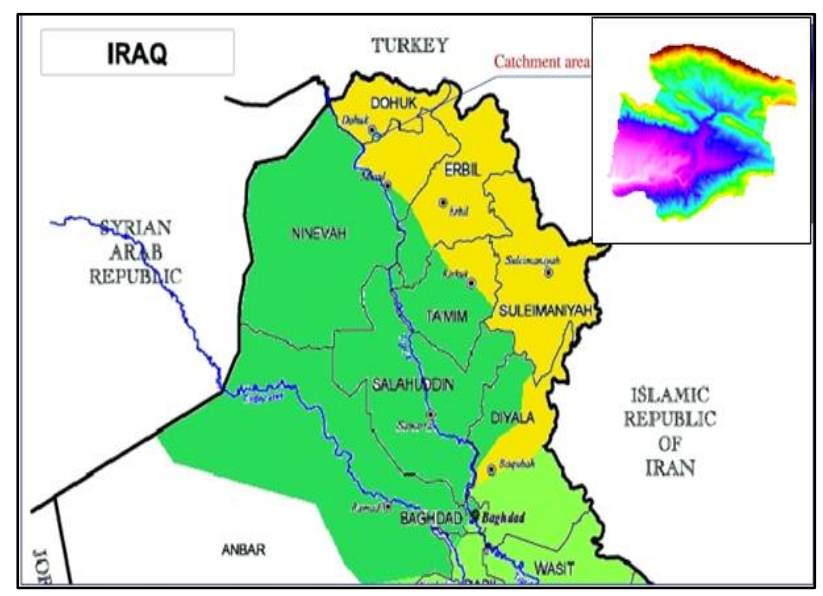

Figure 1: Location of Gali-Bandawa Watershed 


\section{Materials and Method}

In this study, a variety of data including the Digital Elevation Model (DEM 30m), Metrological data of rainfall have been obtained for the year 2001-2014 from the Directorate of Duhok Dam in Iraq. Land use map is obtained by classifying the Landsat image from the USGS website. In this study, the runoff estimation is summarized in a flowchart as shown in Figure (2)

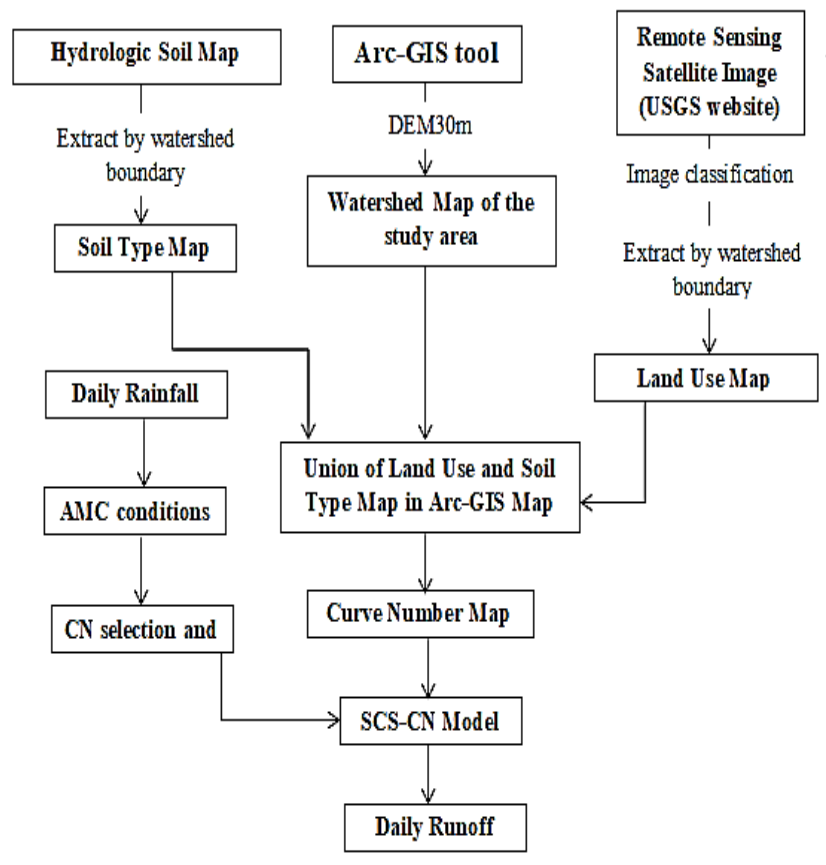

Figure 2: Flowchart of Rainfall-Runoff Estimation processes.

\subsection{Soil Type Map Preparation}

The Soil Map of a part of Duhok governorate by Ameen (2016). It's extracted to fit the selected Gali-Bandawa Watershed using GIS tools as shown in Figure (4).

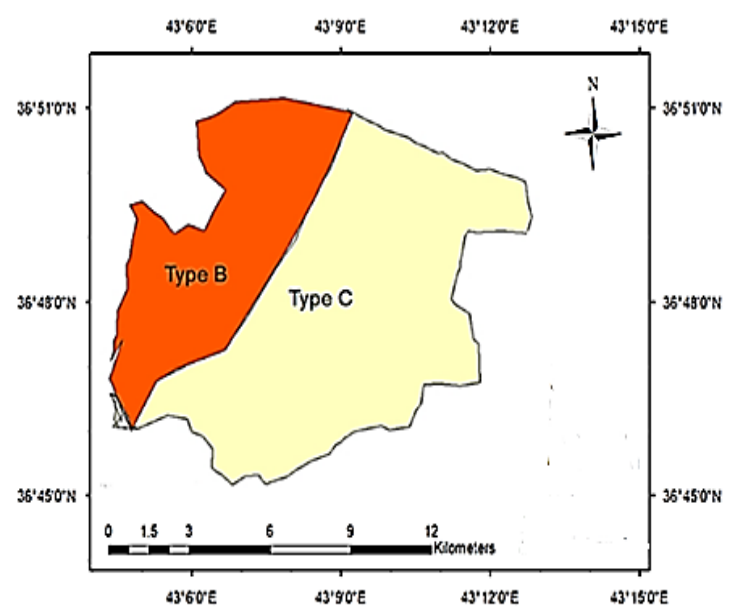

Figure 3: Land use map of Gali Bandawa.
Two types of soil are classified for Gali-Bandawa watershed; they are Type B and Type C, both types of soil are described as shown in Table (1).

TABLE 1: Soil Type Classification

\begin{tabular}{|c|c|c|}
\hline $\begin{array}{l}\text { Type of } \\
\text { Soil }\end{array}$ & Drainage Area $=92$ sq. $\mathrm{Km}$ & $\begin{array}{c}\text { Percentage } \\
\%\end{array}$ \\
\hline B & $\begin{array}{l}\text { Moderately deep, well-drained, } \\
\text { with moderately fine to coarse } \\
\text { texture. Soils having a moderate } \\
\text { infiltration rate. }\end{array}$ & $40 \%$ \\
\hline C & $\begin{array}{l}\text { Clay loam, shallow sandy loam. } \\
\text { These soils have a slow rate of water } \\
\text { transmission. }\end{array}$ & $60 \%$ \\
\hline
\end{tabular}

\subsection{Land Use and Land Cover preparation}

The Landsat image is used to create land use/Landover map Figure (3) using Arc GIS to prepare a land-use pattern of the study area.

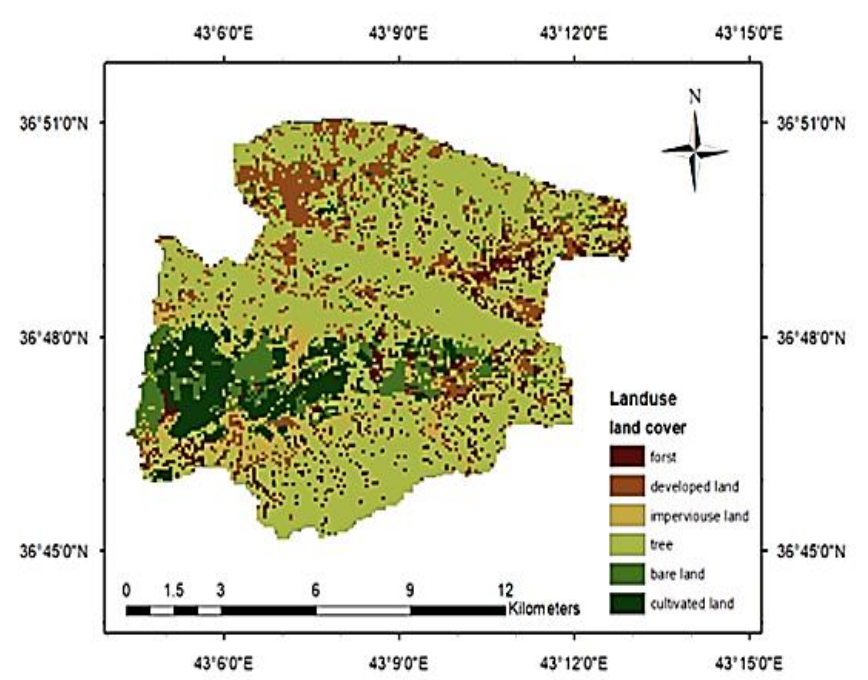

Figure 4: Soil Type Map of Gali Bandawa.

The original land-use types were grouped into six groups as cultivated, forest, tree, and impervious, urban, and bare land. Table (2) shows the percentage of land use classes after classification is satisfied.

Table 2: Land use_ land cover Statistical data

\begin{tabular}{clc}
\hline \hline NO. & Land Use Area=92 sq.km & Percentage \% \\
\hline 1 & Frost & 7 \\
2 & Developed land & 11 \\
3 & Impervious land & 8 \\
4 & Tree & 58 \\
5 & Bare land & 7
\end{tabular}



$6 \quad$ Cultivated land
$\sum$
Total
100

\subsection{SCS CURVE NUMBER METHOD}

The SCS-CN method is developed by the USDA in 1954. This method is based on a water balance equation and other two functional hypotheses. The first hypothesis shows that both quantity are the same, depth of runoff $\mathrm{q}$ is less than or equal to depth of precipitation $\mathrm{P}$, also $\mathrm{F}_{\mathrm{a}}$ is the water depth retained in a watershed is equal or less than to some maximum potential retention $S . I_{a}$ is initial abstraction for which no runoff occur, so $P-I_{a}$ is the potential runoff (Chow, 2002). As shown in equation (1)

$$
\frac{\mathrm{Fa}}{\mathrm{S}}=\frac{\mathrm{q}}{\mathrm{P}-\mathrm{I}_{\mathrm{a}}}
$$

While the other hypothesis assumes that the amount of initial abstraction is part of the maximum potential retention (Engineering Hydrology Handbook by Subramanya K).

The weighted curve number is calculated after recognizing the $\mathrm{CN}$ for $\mathrm{N}$ number of land classes using equation (2).

$$
\mathrm{CNw}=\frac{\sum_{\mathrm{i}}^{\mathrm{N}} \mathrm{CNi} * \mathrm{Ai}}{\sum_{\mathrm{i}}^{\mathrm{N}} \mathrm{Ai}}
$$

Where: $\mathrm{CNw}$ is the weighted curve number, $\mathrm{CNi}$ is the curve number for a particular land class unit $i$ to $n$, and $\mathrm{Ai}$ is the area of the particular land class $\mathrm{i}$.

$$
\begin{array}{ll}
\mathrm{q}=\frac{\left(\mathrm{P}-\mathrm{I}_{\mathrm{a}}\right)^{2}}{\mathrm{P}-\mathrm{I}_{\mathrm{a}}+\mathrm{S}} & \text { if } \mathrm{P}>0.05 \mathrm{~S} \\
\mathrm{q}=0 & \text { if } \mathrm{P}<0.05 \mathrm{~S}
\end{array}
$$

Where: $\mathrm{q}$ is the runoff depth (L), $\mathrm{P}$ is the total depth of rainfall $(\mathrm{L})$, and $\mathrm{I}_{\mathrm{a}}$ is the initial abstraction $(\mathrm{L})$. Finally, $\mathrm{S}$ is the abstraction coefficient, it represents the upper infiltration in soil and is increased with decreasing of curve number value.

$$
S=\frac{25400}{C N}-254
$$

Recently, It has been assumed that $\mathrm{I}_{\mathrm{a}}=0.2 \mathrm{~S}$ (Chow, 2002), another recent research estimated that $I_{a}=0.05 \mathrm{~S}$ may by more accurate relationship (Hawkins et al., 2002). The relationship $I_{a}=0.2 \mathrm{~S}$ has been used widely for the experimental study of small watersheds; more recent methods were analyzed to determine the relationship between $\mathrm{I}_{\mathrm{a}}$ and $\mathrm{S}$ with many other data of rainfall and runoff from numerous U.S. watersheds done by Hawkins et al. (2002). The runoff depth was improved to the following equation:

$$
\mathrm{q}=\frac{\left(\mathrm{P}-0.05 \mathrm{~S}_{0.05}\right)^{2}}{\mathrm{P}+0.95 \mathrm{~S}_{0.05}}
$$

In equation (6) the term $\mathrm{S}_{0.05}$ is different from the one that used for runoff estimation with $I_{a}=0.2 \mathrm{~S}$ (here $\mathrm{S}$ represented by $\mathrm{S}_{0.2}$ ). A relationship was derived $\mathrm{S}_{0.05}$ from $\mathrm{S}_{0.2}$ as shown in the following equation:

$$
\mathrm{S}_{0.05}=1.33 \mathrm{~S}_{0.2}^{1.15}
$$

\subsection{Antecedent Moisture Condition, AMC}

Antecedent moisture condition (AMC) of the rainfallrunoff event refers to the amount of moisture content found in the soil at the beginning before the rainfall. Both initial abstraction and infiltration are governed by AMC.

If the summation of rainfall for the previous five days is less than 1.4 inches; dry condition of soil is assumed, and $\mathrm{CN}$ is converted to (CNI) using equation (8)

$$
\mathrm{CN}(\mathrm{I})=\frac{4.2 \mathrm{CN}(\mathrm{II})}{10-0.058 \mathrm{CN}(\mathrm{II})}
$$

But, if the summation of rainfall is greater than 2.1 inches; then wet condition of soil is assumed, and $\mathrm{CN}$ is converted to (CNIII) using equation (9) 


$$
\mathrm{CN}(\mathrm{III})=\left(\frac{23 \mathrm{CN}(\mathrm{II})}{10+0.13 \mathrm{CN}(\mathrm{II})}\right)
$$

The antecedent 5 days rainfall has been used as an index to fit the antecedent moisture conditions (Al-Jabari et. al., 2009) in Table (3)

TABLE 3: Antecedent Moisture Condition (AMC)

\begin{tabular}{|c|c|c|}
\hline \multirow{2}{*}{ AMC } & \multicolumn{2}{|c|}{$\begin{array}{l}\text { Total 5-day antecedent rainfall } \\
\qquad(\mathrm{mm})\end{array}$} \\
\hline & $\begin{array}{l}\text { Dormant } \\
\text { season }\end{array}$ & $\begin{array}{l}\text { Growing } \\
\text { season }\end{array}$ \\
\hline I & $<12.7$ & $<35.6$ \\
\hline II & $12.7-27.9$ & $35.6-53.3$ \\
\hline III & $>27.9$ & $>53.3$ \\
\hline
\end{tabular}

\subsection{FORTRAN (90) Programming}

Language of FORTRAN programming was the highest level language, H.L.L. developed in 1954 for IBM Company. It stands for FORmula-TRANslation, used for solving both scientific and engineering issues by using symbolic names to inform mathematical equations in a comprehensible form. FORTRAN program also control structures than include conditional IF statement, DO loops (repeated loops), and a GOTO statement (Hemmendinger, 2000).

\section{Results and Discussions}

By using the extension of Hec-GeoHMS in GIS, the curve number Grid map can be created by merging land use and soil type maps as shown in figure(4)

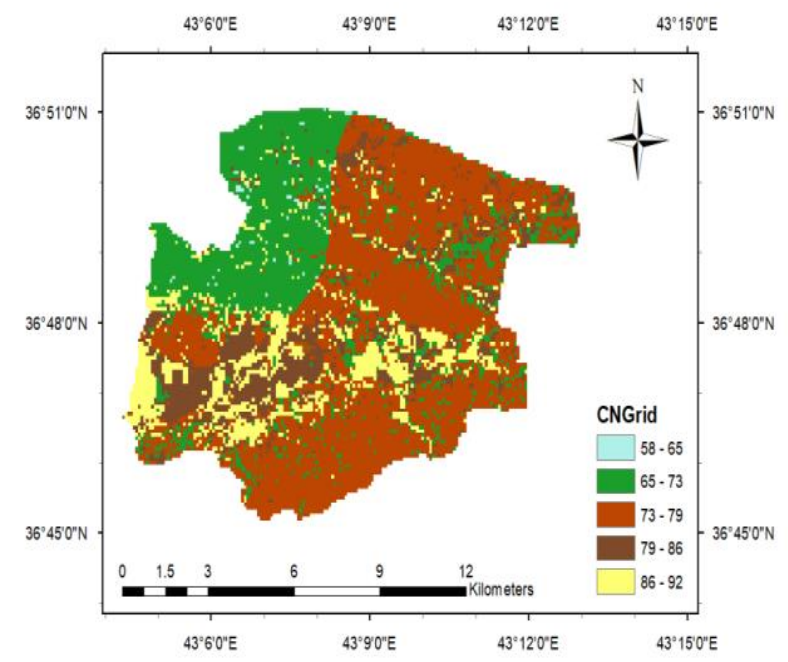

Figure 4: CN Grid map of Gali Bandawa watershed
The $\mathrm{CN}$ value for each soil hydrologic group and corresponding land use classes are presented in Table (4) (USDA, 1986).

TABLE 4: Values of Curve Number (CN)

\begin{tabular}{|c|c|c|c|c|}
\hline Land Use & $\begin{array}{c}\text { Hydrologi } \\
\text { c soil group }\end{array}$ & $\begin{array}{l}\mathrm{CN} \\
\end{array}$ & $\begin{array}{r}\text { Area } \\
(\mathrm{Km} 2)\end{array}$ & $\begin{array}{r}\text { Percentag } \\
\text { e of Area }(\%)\end{array}$ \\
\hline \multirow{2}{*}{ Forest } & (B) & 58 & 0.92 & 1 \\
\hline & (C) & 72 & 5.52 & 6 \\
\hline \multirow{2}{*}{ Urban } & (B) & 69 & 4.58 & 5 \\
\hline & (C) & 79 & 5.62 & 6 \\
\hline Imperviou & (B) & 89 & 1.92 & 2 \\
\hline s Land & $(\mathrm{C}))$ & 92 & 5.13 & 6 \\
\hline \multirow{2}{*}{ Tree } & (B) & 65 & $\begin{array}{l}12.7 \\
4\end{array}$ & 13 \\
\hline & (C) & 76 & $\begin{array}{l}40.3 \\
8\end{array}$ & 44 \\
\hline \multirow{2}{*}{ Bare Land } & (B) & 86 & 1.49 & 2 \\
\hline & (C) & 91 & 5.09 & 6 \\
\hline Cultivated & (B) & 73 & 2.5 & 3 \\
\hline Land & (C) & 82 & 5.88 & 6 \\
\hline
\end{tabular}

The weighted curve number for the Gali Bandawa watershed is:

$$
\begin{aligned}
\mathrm{CNw} & =\frac{7007}{92} \\
& =76
\end{aligned}
$$

The $\mathrm{CN}$ is rounded 76 as the normal condition (AMCII), $\mathrm{CN}$ for the other two conditions; the dry condition (AMCI) and the wet condition (AMCIII) were obtained using equations (6) and (7):

$$
\begin{aligned}
& \mathrm{CN}(\mathrm{I})=58, \\
& \mathrm{CN}(\mathrm{III})=88
\end{aligned}
$$

Before estimation of the runoff depth $\mathrm{q}$ in equation (2) the value of $(S)$ must be determined for each antecedent moisture condition (AMC) as summarized in the Table (5).

TABLE 5: Values Used in Hydrological Equations

\begin{tabular}{cccc}
\hline \hline $\begin{array}{c}\text { AMC } \\
\text { condition }\end{array}$ & $(\mathrm{CN})$ & $\mathrm{S}$ & $\mathrm{P}>0.05$ \\
\hline I & 58 & 7.241 & 2.172 \\
II & 76 & 3.158 & 0.947 \\
III & 88 & 1.364 & 0.409 \\
\hline
\end{tabular}


As a result of the calculations, based on the SCS method, it was found that the average annual surface runoff rate (depth) for the period (2001-2014) in Bandawa watershed is around $70 \mathrm{~mm}$ which represented $11.4 \%$ of the total annual rainfall. The annual rainfall and runoff during (2001-2014) in the study area are shown in Table (6).

TABLE 6: The annual runoff from period 2001 to 2014

\begin{tabular}{lccc}
\hline \hline Year & $\begin{array}{c}\text { Annual Rainfall } \\
(\mathrm{mm})\end{array}$ & $\begin{array}{c}\text { Annual } \\
(\mathrm{mm})\end{array}$ & Runoff \\
\hline 2001 & 445.10 & 70.02 \\
2002 & 742.28 & 178.98 \\
2003 & 689.46 & 116.10 \\
2004 & $1,068.61$ & 73.49 \\
2005 & 511.65 & 34.83 \\
2006 & 806.32 & 111.26 \\
2007 & 430.46 & 47.02 \\
2008 & 387.85 & 10.46 \\
2009 & 587.26 & 57.93 \\
2010 & 363.10 & 11.64 \\
2011 & 464.73 & 17.93 \\
2012 & 559.95 & 27.70 \\
2013 & 836.55 & 59.17 \\
2014 & 778.50 & 168.09 \\
Mean & 619.42 & 70.33 \\
\hline \hline
\end{tabular}

The findings showed that the maximum runoff happened in month January and the minimum value was in month May, and finally, there was no runoff in months June, July, and August as there was no rainfall as shown in figure (5)

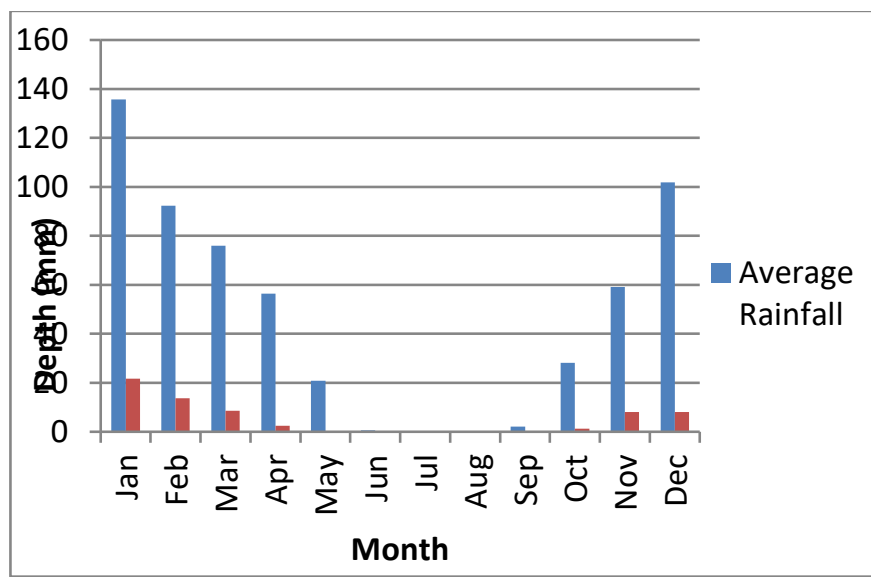

Figure 5: Average rainfall and runoff for the period (20012014)

\section{Conclusion}

SCS-CN method has been used for calculating the runoff for Gali Bandawa ungauged watershed having an area of $92 \mathrm{~km}^{2}$. Land use and soil type maps have been prepared using GIS to find out the CN map of the study area to determine the runoff. Types B and type C of soil have been classified within the region, six classes of land use were categorized, namely; forest, urban, impervious land, tree, bare land, and cultivated land. $\mathrm{CN}$ values range from 58 to 92 , and weighted $\mathrm{CN}$ is 76 . Daily rainfall data for the years 2001-2014 was used to compute the daily runoff depth at these years. It should be noticed that GIS tool helps in more accurate determination of morphological of the basin and classification of land-use map

FORTRAN programming has been used to apply the SCS-CN method on the daily rainfall data to facilitate the calculations as shown in appendix A. The result showed that the average annual runoff was $70.33 \mathrm{~mm}$ and represent $11.4 \%$ of the average annual rainfall. Besides that, the maximum runoff happened in month January, and minimum values of runoff happened in May. The estimated runoff of this area is useful for managing the Gali-Bandawa watershed. Various conservation measures could be planned using the same applied approach.

\section{REFERENCES}

1. Ameen, Sh. A. (2016), Soil erosion in the Duhok district, Its measured, risks, and maintenance. Master Thesis. (P) 56. University of Duhok/ College of Humanity/ Geography Department Not published

2. Al-Ansari, N.A., (1998), Water Resources in the Arab countries: Problems and possible solutions. UNESCO International Conference, Paris, 367- 376.

3. Al-Ansari, N.A., and Knutsson, S. (2011), Toward prudent management of water resources in Iraq. Journal of Advanced Science and Engineering Research, 1, 53-67.

4. Al-Jabari, S., Abu Sharkh, M, Al-Mimi, Z. (2009), Estimation of Runoff for Agricultural Watershed Using SCS Curve Number And GIS Thirteenth International Water Technology Conference, IWTC 13, Hurghada, Egypt.

5. Eshanthini P, P. Vijayalakshmi, P.K. Raji, Rainfall Runoff Estimation Using SCS Model and Arc GIS for Micro Watershed in Cuddalore District. International Journal of Civil Engineering and Technology, 9(9), 2018, pp. 990-996.

6. Hawkins, R.H.; Jiang, R.; Woodward, D.E.; Hjelmfelt, A.T.; Van Mullem, J.A. (2002).Runoff Curve Number Method: Examination of the Initial Abstraction Ratio. 
Proceedings of the Second Federal Interagency Hydrologic Modeling Conference, Las Vegas, Nevada (U.S. Geological Survey).

7. Hemmendinger, D. (2019). Computer programming language. Encyclopædia Britannica

8. Ketul Shah, A. T. Motiani, Indra Prakash, Khalid Mehmood (2017), Application of SCS-CN Method for Estimation of Runoff Using GIS, International Journal of Advance Engineering and Research Development Volume 4, Issue 4, e-ISSN (O): 2348-4470 p-ISSN (P): 23486406.

9. Khidir Kh. M. and Al-Sha'ar M. T.: 2017, Estimating Storm Direct Runoff Using Synthetic Unit Hydrograph Methods By (WMS) Model (Solag Basin as a Case Study)', Journal of University of Duhok, Vol. 20, No.1 (Pure and Eng. Sciences), Pp 727-735.

10. Lange, J., Ghanem, M., Hussary, S., Leibundgut, Ch., and Greenbaum, N. (2000), Tracer Techniques in Sprinkling Tests to Study Runoff Generation in A Rocky Mediterranean Karts environment, Institute of Hydrology, University of Freiburg, Fahnenbergplatz, Freiburg, Germany.

11. Engineering Hydrology Handbook of Subramanya K

12. Ponce, V. M., and Hawkins, R.H. (1996). Runoff Curve Number: Has It Reached Maturity?, ASCE J. Hydrologic Engineering, 1(1), 11-19.

13. United States Department of Agriculture (1986). Urban hydrology for small watersheds.

14. Shadeed, S, Almasri, M (2010). Application of GIS-based SCS-CN method in West Bank catchments, Palestine. Water Science and Engineering, 2010, 3(1): 1-13

15. Saleh Zakaria, Yaseen T. Mustafa, Diary A. Mohammed, Salahalddin Saeed Ali, Nadhir Al-Ansari, Sven Knutsson (2013), Estimation of annual harvested runoff at Sulaymaniyah Governorate, Kurdistan Region of Iraq. Natural Science 5 (2013) 1272-1283

16. Ameen, Sh. A. (2016), , Master Thesis, not puplished.

17. UNDP (2011) Drought impact assessment, recovery and mitigation framework and regional project design in Kurdistan region.

18. USDA, Soil Conservation Service (1985), National Engineering Handbook, USA.

19. Chow, V. T., Maidment, D. R., and Mays, L. W. (2002), "Applied Hydrology", McGraw-Hill Book Company, New York, USA

20. Yannopoulos S., Katsi, A., and Papamichail, D. (2005). Rainfall-Runoff Process Simulation using the Watershed Modeling System (WMS) software. Proceedings of 6th International Conference of European Water Resources Association, Menton, France: pp. 111-122 


\section{Appendix A}

\section{Computer programing using FORTRAN 90}

Real R(6000),CN(20),AREA(20)

open(5,file='Rain.in')

open(6,file='Rain.out')

!clculating cnII for $\mathrm{cni}=12$ and area $=12$

do $\mathrm{i}=1,12$

$\operatorname{read}\left(5,{ }^{*}\right) \mathrm{CN}(\mathrm{i}), \mathrm{AREA}(\mathrm{i})$

enddo

do $\mathrm{i}=1,12$

sumCN_area $=$ sumCN_area + cn $(\mathrm{i}){ }^{*} \mathrm{AREA}(\mathrm{i})$

sumAREA =sumAREA+AREA(i)

enddo

$\mathrm{CNII}=$ sumCN_area/sumAREA

write $\left(6,{ }^{*}\right)^{\prime} \mathrm{CNII}={ }^{\prime}, \mathrm{CNII}$

!----reading and writting all rainfall data----

do $i=1,5540$

$\operatorname{read}(5, *) \mathrm{R}(\mathrm{i})$

!write $\left(6,{ }^{*}\right) \mathrm{R}(\mathrm{i})$

enddo

!----reading and writting previous five days $(k=5)---$

$\mathrm{k}=5 ; \mathrm{n}=5542$

do $\mathrm{i}=0, \mathrm{n}-1$

sumR $=0$

do $\mathrm{j}=\mathrm{i}+1, \mathrm{k}$

! write $\left(6,{ }^{*}\right) R(j), j$

$\operatorname{sumR}=\operatorname{sumR}+R(j)$

enddo

!write $\left(6,{ }^{*}\right)$ 'sumR=',sumR

if ( $\left.\operatorname{sumR}<1.4^{*} 25.4\right)$ then

$\mathrm{CNI}=(4.2 * \mathrm{CNII}) /(10-0.058 * \mathrm{CNII})$

S_2 $=(25400 / \mathrm{CNI})-254$

S_5 $=1.33^{*}$ s_2

$q=\left(R(j+1)-0.05^{*} s \_5\right)^{* * 2} /\left(R(j+1)+0.95^{*} s \_5\right)$

write $\left(6,{ }^{*}\right)$ 'dry conditions" CNI',CNI ,' $q=', q$,' rain=', $R(j+1)$

!write $\left(6,{ }^{*}\right)^{\prime}$ s_2',s_2,' s_5',s_5,' q',q

elseif(sumR $>=35.56$. and.sumR $<=53.34)$ then

!sumR $<=1.4 * 25.4$.and.sumR $>=2.1 * 25.4$ )

S_2 $=(25400 / \mathrm{CNII}) / 254$

$\mathrm{S} \_5=1.33^{*} \mathrm{~S} \_2$

$q=\left(R(j+1)-0.05 * s \_5\right)^{\star *} 2 /\left(R(j+1)+0.95 * s \_5\right)$

\section{Appendix B}

Computer programing using FORTRAN 90

write $\left(6,{ }^{*}\right)$ 'mediam condition',' $\mathrm{CNII}=$ ',CNII , $\mathrm{q}=$ ', $\mathrm{q}$, ' rain ${ }^{\prime}, \mathrm{R}(\mathrm{j}+1)$

elseif(sumR>2.1*25.4)then

$\mathrm{CNIII}=\left(23^{*} \mathrm{CNII}\right) /\left(10+0.13^{*} \mathrm{CNII}\right)$

s_2=(25400/CNI) -254

S_5 $=1.33^{*}$ S_2

$\mathrm{q}=\left(\mathrm{R}(\mathrm{j}+1)-0.05^{*} \mathrm{~s} \_5\right)^{* *} 2 /\left(\mathrm{R}(\mathrm{j}+1)+0.95^{*} \mathrm{~s} \_5\right)$

write $\left(6,{ }^{*}\right)$ wet conditions" CNIII',CNIII ,' $\mathrm{q}=$ ', $\mathrm{q}$,'

rain ${ }^{\prime}, R(j+1)$

!write $\left(6,{ }^{*}\right)^{\prime}$ s_2',s_2,'s_5',s_5,' q',q

else

endif

$\mathrm{k}=\mathrm{k}+1$

write $(6, *)^{\prime}$

!write $\left(6,{ }^{*}\right)$ 'last value', $\mathrm{R}(\mathrm{J})$

!write $\left(6,{ }^{*}\right)$ 'sumR',sumR

!if (i==n-1)goto 30

if $(\mathrm{i}==\mathrm{n}-6)$ goto 30

enddo

30 write $\left(6,{ }^{*}\right)$ 'end of program'

stop

end 